of that activity are overlooked. British industry has an unenviable record for looking innovatory gift-horses in the mouth. Applied research, being part way towards development, is more labour-intensive than basic research. Has anybody in Britain calculated how little will be accomplished by re-treaded academics? The morale of the scientific community matters more than its organization or budget. And, in Britain, morale is near rockbottom.

The next few months will tell whether such arguments, sustained by the necessarily dated evidence of ABRC's two reports, will carry weight with a government that, so far, has been indifferent to them. Some sign of which way the wind is blowing should come next month, when estimates of public spending for the next three years will be published. The chances are not bright. All the arguments have been made before. And, given the unavoidable delay in the compilation of statistics on the pattern of research spending and achievement, there is little that $\mathrm{ABRC}$ can do in the time available to prove the most chilling assertion about the condition of British science: it is so long since a bright person with a bright idea could reckon on finding the support needed for its pursuit that creative people know their future lies outside Britain (where good work is, in any case, better rewarded).

In the long run, that is how the enterprise will be killed off. The most skilled will leave, leaving the conduct of research and the education of the young to those, not an unbiased sample, who happen not to have done so. Meanwhile, the institutions most at risk, the universities and the research institutes, will most probably compliantly wait for the reforms that could give them a better chance on the leisurely proceedings of complicated committee networks certain to yield compromised halfreforms. The planned change in the transition between secondary and higher education in Britain is a case in point. After twenty years in which far-sighted universities have conspired with short-sighted governments to preserve the uniquely specialized character of secondary education, it is now planned that there should be a marginally broader curriculum leading from school to higher education two years from now. In a decade or so, entrants to the research professions may be marginally more broadly educated than has been the rule, although still more blinkered than in most other places. But why wait ten years for an unsatisfactory solution of a long-standing problem? Why, in the field of public administration in which ABRC is charged with responsibility, wait for the benefits of the slow processes by which UGC plans to concentrate research activity on the more productive universities? Could not those in charge find a quicker way? Or find others who might take the risk? The trouble with these conservative societies is that they require that institutions under pressure should be compliant in their own decline. The present management has commissioned two useful reports. Might it not also speak out and say what should now be done? The British government might not listen, but the troops would be modestly encouraged.

\section{UNESCO's new future?}

\section{Member governments of the UN's chief cultural} agency should seize the opportunity for reform.

THERE are two views of UNESCO, the United Nations Educational, Scientific and Cultural Organisation. One is that its constitution is so vague and its ambitions so far-reaching that very little should ever have been expected of it. Another is that it is a splendid organization which, by bad luck, has recently fallen on hard times, sacrificing in the process the membership of the United States, Britain and Singapore. The truth most probably lies somewhere in between. There may also be some who hold that UNESCO is a splendid organization which remains in splendid condition, but little has been heard from them in the recent past. Whichever may be the correct opinion, the mem- bers of UNESCO will have an opportunity in the next few months to edge the organization in a direction better suited to an intelligent reading of its purpose.

The immediate occasion is that the director-general for the past ten years, Mr Amadou-Mahtar M'Bow, is coming to the end of his second term in office. Already, the executive board in Paris is searching for possible successors, not necessarily incommoded by the position on the issue of Mr M'Bow, who has said that he will not seek a third term but will not decline to serve if asked. Mr M'Bow personally has been at the bottom (or top) of many of UNESCO's troubles in the past troubled decade. $\mathrm{He}$ appears to have brought to the organization a style of management that left simple servants of UNESCO in perpetual uncertainty about their functions or even the continuation of their jobs, although there may be nothing more to this than the way in which vain people often demand unsustainable loyalty from their colleagues. Mr M'Bow's more real failing is that he has done so little that can be called new. He was personally committed to the scheme for creating a "new world information order" which, whatever its rights and wrongs (the second predominated), might have been calculated to drive away the United States at least; curiously, with the departure of the United States two years ago, very little has been heard of this strange proposal. It would be in the organization's best interests that Mr M'Bow should on this occasion be taken at his word, and allowed peacefully to pursue other interests. It would be disastrous if he were to stay.

The issue of who shall be director-general is, unfortunately, only a small part of UNESCO's problem and, most probably, more a symptom than a cause. Since its foundation in the heady days at the end of the Second World War, UNESCO seems profoundly to have lost a sense of what it is about. Although the organization's budget has never been as big as that of a dozen or so private foundations in the United States, its members have allowed it to interpret its field of action (and competence) in the widest way, and have urged it to become a kind of impoverished aid agency as well.

The organization is also perpetually undecided about the function of its staff. Is UNESCO a grant-making agency, or a kind of ivory tower whose occupants have the wisdom and the practical experience to solve problems at which others have failed? Disastrously, UNESCO has from the outset nursed the second conceit. What its members should now seek is a formula that would allow the human beings who work loyally for it to do work that is within their competence, a quality that itself has been eroded after several years of quarrelling. Can that be too much to ask?

Unhappily for some of UNESCO's well-wishers, a move in that direction would not necessarily bring lapsed members rushing back to the fold. A large part of the reason why the United States and, later, Britain left was their belief that UNESCO had become "politicized". To the extent that that amounts to a protest against the habit of groups of UNESCO members of ganging up against each other, the charge is valid. But disaffected Western governments have too often in the past complained about UNESCO simply because many of the issues that crop up are intrinsically political. It is, for example, squarely within UNESCO's terms of reference to worry about the preservation of important archaeological sites; doing that diligently must step on sovereign toes. The same is true of other important issues that UNESCO has successfully negotiated, copyright for example. Even the new world information order was a proper subject for UNESCO to take up; the fault was merely that an undistinguished director-general allowed a biased proposal to take the centre of the stage. A wiser person would not necessarily have won friends among those who took offence, but might have accomplished something. The lesson is that Britain and the United States should not pretend that reentry would be a bed of roses. UNESCO membership will always need a strong stomach. 